\title{
HUBUNGAN PENDAPATAN ASLI DAERAH, DANA ALOKASI UMUM, DAN DANA BAGI HASIL DENGAN ANGGARAN BELANJA MODAL PADA KABUPATEN DAN KOTAMADYA DI JAWA BARAT
}

\author{
Oleh: \\ Alfira Sofia \\ (Dosen Program Studi Akuntansi Fakultas Pendidikan Ekonomi \& Bisnis UPI) \\ Iklil Syamsurizal \\ (Alumni Program Studi Akuntansi Fakultas Pendidikan Ekonomi \& Bisnis UPI)
}

\begin{abstract}
Abstrak
Peningkatan pelayanan publik merupakan hasil yang ingin dicapai oleh pemda dan DPRD dilakukan melalui salah satunya dengan sebuah kebijakan anggaran terutama untuk Anggaran Belanja Modal, dalam bentuk investasi berupa aset daerah yang menunjang kegiatan publik. Penelitian ini menggunakan metode korelasional, dengan analisis korelasi. Objek penelitian yang juga sebagai populasi dan sampel dalam penelitian ini adalah dua puluh lima kabupaten dan kotamadya di Jawa Barat. Adapun data yang digunakan merupakan LRA APBD dari Badan Pemeriksa Keuangan. Dan analisis data menggunakan pengujian nilai korelasi parsial dan simultan. Penelitian ini menunjukkan secara parsial Pendapatan Asli daerah, Dana Alokasi Umum, dan Dana Bagi Hasil memiliki hubungan dengan Anggaran Belanja Modal. Sedangkan secara simultan menunjukkan bahwa Pendapatan Asli Daerah, Dana Alokasi Umum, dan Dana Bagi Hasil memiliki hubungan dengan Anggaran Belanja Modal.
\end{abstract}

Kata Kunci: Pendapatan Asli Daerah, Dana Alokasi Umum, Dana Bagi Hasil, dan Anggaran Belanja Modal.

\section{Latar Belakang}

Sejalan perubahan peraturan perundangan yang mendasari pengelolaan keuangan Pemerintah Daerah (Pemda) yakni dengan diamandemennya UU No. 22 tahun 1999 dengan UU No. 32 tahun 2004 tentang Pemerintahan Daerah. Dan juga diikuti dengan amandemen atas Permendagri No. 13 tahun 2006 menjadi Permendagri No. 59 tahun 2007 tentang Pedoman Pengelolaan Keuangan Daerah. Terlepas dari perubahan perundangan tersebut, pengalokasian sumber daya ke dalam anggaran belanja modal (capital expenditure) merupakan sebuah proses yang sarat dengan kepentingan-kepentingan politik. Anggaran ini sebenarnya dimaksudkan untuk memenuhi kebutuhan publik akan sarana dan prasarana umum yang disediakan oleh Pemda. Namun, adanya kepentingan politik dari Legislatif yang terlibat dalam proses penyusunan anggaran menyebabkan alokasi anggaran belanja modal sering tidak efektif dalam memecahkan permasalahan publik.

Dalam hal ini peran Pemda sebagai pihak Eksekutif dan Dewan Perwakilan Rakyat Daerah (DPRD) sebagai pihak Legislatif, menjadi penentu dalam melakukan kebijakan anggaran yang akan diambil. Kebijakan anggaran merupakan sebuah produk hukum perundang-undangan hasil kerjasama antara kedua lembaga tersebut. "Berdasarkan pembedaan peran dan persaman fungsi Legislatif dan Eksekutif, menunjukkan bahwa antara Legislatif dan Eksekutif terjadi hubungan keagenan" (Halim, 2001; Halim \& Abdullah, 2006). Pada pemerintahan, peraturan perundangan secara implisit merupakan bentuk kontrak antara Eksekutif, Legislatif, dan publik.

Menurut Frceman (dalam Nordiawan, 2007: 19) anggaran adalah sebuah proses yang dilakukan oleh organisasi sektor publik untuk mengalokasikan sumber daya yang dimiliki kedalam kebutuhan-kebutuhan yang tidak terbatas. Anggaran 
daerah merupakan rencana keuangan yang menjadi dasar dalam pelaksanaan pelayanan publik.

Di Indonesia, dokumen anggaran daerah disebut Anggaran Pendapatan dan Belanja Daerah (APBD), baik untuk propinsi maupun kabupaten dan kotamadya. Proses penyusunan anggaran pasca UU No. 32 tahun 2004 melibatkan dua pihak yaitu Eksekutif dan Legislatif. Dan masing-masing melalui sebuah tim atau panitia anggaran. Adapun Eksekutif sebagai pelaksana operasionalisasi daerah, berkewajiban membuat draft atau rancangan $\mathrm{APBD}$, yang hanya bisa diimplementasikan jika sudah disahkan DPRD dalam proses ratifikasi anggaran.

Lingkup anggaran terutama untuk alokasi anggaran belanja modal, menjadi relevan dan penting di lingkungan Pemda. Hal ini terkait dengan dampak anggaran terhadap kinerja Pemda, sehubungan dengan fungsi Pemda dalam memberikan pelayanan kepada masyarakat. Selanjutnya, DPRD akan mengawasi kinerja Pemda melalui anggaran. Bentuk pengawasan ini sesuai dengan agency theory, dimana Pemda sebagai agen dan DPRD sebagai principal. Hal ini menyebabkan penelitian di bidang anggaran pada suatu Pemda menjadi relevan dan penting.

Sehingga pergeseran komposisi belanja merupakan upaya logis yang harus dilakukan Pemda setempat dalam rangka meningkatkan tingkat kepercayaan publik. Pergeseran komposisi belanja terhadap belanja modal ditujukan untuk peningkatan investasi modal dalam bentuk aset tetap, yakni peralatan, bangunan, infrastruktur, dan harta tetap lainnya. Semakin tinggi tingkat investasi modal diharapkan mampu meningkatkan kualitas pelayanan publik, karena aset tetap yang dimiliki sebagai akibat adanya belanja modal merupakan prasyarat utama dalam memberikan pelayanan publik oleh Pemda.

Perlu dipahami pula, bahwa 'Anggaran sektor publik pemerintah daerah dalam APBD merupakan output pengalokasian sumber daya". "Adapun pengalokasian sumber daya merupakan permasalahan dasar dalam penganggaran sektor publik' (Key 1940 dalam Fozzard, 2001). Sumber daya sebagai pendapatan Pemda merupakan hal yang sangat sulit untuk ditentukan kepastian akan besarnya. Pemda dituntut kejelian dalam melakukan pengalokasian sumber daya yang dimiliki, baik sumber daya pendapatan dari daerah itu sendiri, maupun sumber daya penerimaan dari luar, berupa Dana Perimbangan dari Pusat.

Dan dengan dukungan otonomi dan desentralisasi fiskal dari pemerintah pusat, menjadi sebuah keharusan untuk Pemda dalam melakukan alokasi anggaran dengan lebih baik lagi. "Tuntutan untuk mengubah struktur belanja menjadi semakin kuat, khususnya pada Pemda yang mengalami kapasitas fiskal rendah" (Halim, 2001). Diharapkan dengan alokasi anggaran yang sesuai dapat meningkatkan pembangunan daerah untuk peningkatan pelayanan publik.

Rumusan Masalah

apakah terdapat hubungan antara Pendapatan Asli Daerah, Dana Alokasi Umum, dan Dana Bagi Hasil secara parsial maupun simultan dengan Anggaran Belanja Modal

\section{Kerangka Pemikiran}

Otonomi daerah dan pengelolaan keuangan Pemda di Indonesia memasuki era baru dengan adanya dukungan Pemerintah Pusat, melalui penetapan UU No. 33 tahun 2004 tentang Pemerintah Daerah dan Permendagri No. 59 tahun 2007 (amandemen Permendagri No. 13 tahun 2006) tentang Pedoman Pengelolaan Keuangan Pemerintah Daerah. Pemda diharapkan dapat meningkatkan efisiensi, efektivitas, dan akuntabilitas sektor publik di Indonesia. Salah satunya dalam menentukan kebijakan anggaran yang sesuai dengan kebutuhan publik.

Dalam hal kebijakan anggaran, peran Pemda sebagai pihak eksekutif dan DPRD 
sebagai pihak legislatif, menjadi sangat penting dalam pengambilan keputusan. Kebijakan anggaran merupakan sebuah produk hukum perundang-undangan hasil kerjasama antara kedua lembaga tersebut. "Berdasarkan perbedaan peran dan persamaan fungsi legislatif dan eksekutif, menunjukkan bahwa antara legislatif dan eksekutif terjadi hubungan keagenan" (Halim, 2001; Halim \& Abdullah, 2006). Pada pemerintahan, peraturan perundangan secara implisit merupakan bentuk kontrak antara eksekutif, legislatif, dan publik.

Sebelum menghasilkan sebuah kebijakan anggaran, proses pertama diawali dengan penyusunan APBD dengan membuat kesepakatan antara legislatif dan eksekutif tentang Kebijakan Umum APBD dan Prioritas \& Plafon Angggaran yang berfungsi sebagai pedoman dalam penyusunan APBD. Besarnya kewenangan legislatif dalam proses penyusunan anggaran membuka ruang bagi legislatif untuk "memaksakan" kepentingan. Posisi legislatif sebagai pengawas bagi pelaksanaan kebijakan Pemda, dapat digunakan untuk memprioritaskan kepentingan publik dalam penganggaran. Oleh karena itu, idealnya legislatif merekomendasikan kepada eksekutif untuk menaikkan alokasi pada sektor-sektor yang mendukung kepentingan publik.

Anggaran sektor publik pemerintah daerah dalam APBD sebenarnya merupakan output pengalokasian sumber daya. Adapun pengalokasian sumber daya merupakan permasalahan dasar dalam penganggaran sektor publik (Key 1940 dalam Fozzard, 2001).

Pemda dituntut kejelian dalam melakukan pengalokasian sumber daya yang dimiliki, baik sumber daya pendapatan dari daerah itu sendiri, maupun sumber daya pendapatan dari luar, berupa dana perimbangan dari Pusat. terdiri dari:

Sedangkan menurut Permendagri No 13 tahun 2006 pasal 25, pendapatan Pemda

1. Pendapatan Asli Daerah (PAD)

2. Dana perimbangan

3. Lain-lain Pendapatan Daerah yang Sah

"Pendapatan adalah semua penerimaan daerah dalam bentuk peningkatan aktiva atau penurunan utang dari berbagai sumber dalam periode tahun anggaran bersangkutan" (Abdul Halim, 2002: 64). Dan pada pembahasan ini hanya akan memaparkan dua sumber pendapatan yaitu PAD yang merupakan sumber pendapatan asli daerah dan dana perimbangan yang merupakan sumber pendapatan dari luar daerah, dalam hubungannya sebagai sumber alokasi untuk melakukan pembelanjaan pada anggaran belanja modal. Dana perimbangan sendiri terdiri atas tiga bagian dana. Tetapi yang akan dibahas hanya dua saja, yaitu DAU dan DBH. Sedangkan Dana Alokai Khusus (DAK) sebagai jenis Dana Perimbangan yang ketiga tidak akan dibahas dikarenakan dana ini memiliki sifat sama dengan DAU, yaitu sebagai dana hibah murni. Namun bedanya DAK hanya diberikan kepada Pemda yang melakukan pengajuan dana kepada Pusat. Sehingga tidak setiap Pemda untuk setiap tahun anggaran mendapatkan DAK. Selain itu juga jumlah DAK tidak dominan sebagai sumber pendapatan dalam APBD.

PAD merupakan semua penerimaan daerah yang berasal dari sumber ekonomi asli daerah. Kelompok pendapatan asli daerah dipisahkan menjadi empat jenis yaitu (Abdul Halim, 2002: 65):

1. Pajak daerah

2. Retribusi daerah

3. Bagian laba usaha daerah

4. Lain-lain PAD

Adapun Dana Bagi Hasil adalah dana yang bersumber dari pendapatan APBN yang dialokasikan kepada daerah dengan angka persentase tertentu didasarkan 
atas daerah penghasil untuk mendanai kebutuhan daerah dalam rangka pelaksanaan desentralisasi (Nordiawan, 2007: 49).

Selain karena pertimbangan politis, alasan lain dari pemberian dana $\mathrm{DBH}$ ini adalah untuk mengurangi ketimpangan vertikal (vertical imbalance) antara Pemerintah Pusat dan Daerah. Berdasarkan PP No 55 tahun 2005 pasal 3, terdapat dua sumber DBH yaitu pajak dan sumber daya alam. Sebenarnya DBH merupakan hasil dari pajak dan sumber daya alam yang ada di daerah, dan hasil tersebut dibagi dua dengan Pemerintah Pusat melalui persentase tertentu. Sehingga DBH bukan merupakan dana hibah murni (grants) dari Pemerintah Pusat, melainkan hasil potensi daerah yang dibagi dua dengan Pemerintah Pusat.

DBH dari sumber daya alam berdasarkan PP No 55 tahun 2005 pasal 15, berasal dari kehutanan, pertambangan umum, perikanan, pertambangan minyak bumi, pertambangan gas bumi, serta pertambangan panas bumi. Sedangkan DBH Pajak sendiri terdiri atas Pajak Bumi dan Bangunan (PBB), Bea Perolehan Hak atas Tanah dan Bangunan (BPHTB), serta Pajak Penghasilan ( $\mathrm{PPh}$ ), baik dari wajib pajak orang pribadi dalam negara (WPOPDN) maupun dari PPh pasal 21.

Sedangkan DAU merupakan dana hibah murni (grants) yang kewenangan penggunaan diserahkan penuh kepada Pemda penerima. UU No. 33 tahun 2004 memberikan pengertian bahwa:

Dana Alokasi Umum adalah dana yang bersumber dari pendapatan APBN yang dialokasikan dengan tujuan untuk pemerataan kemampuan keuangan antar daerah, untuk mendanai kebutuhan daerah dalam rangka pelaksanaan desentralisasi.

Adapun jumlah DAU yang diterima oleh kabupaten atau kotamadya dihitung berdasarkan formula berikut:

\section{DAU setiap Pemda}

$$
=90 \% \times 26 \% \times \text { Pendapatan dalam Negeri } \times \text { Bobot Daerah }
$$

(Mardiasmo, 2002:161)

Formula diatas sesuai dengan PP No. 55 tahun 2005 Pasal 37 yaitu:

(2) Jumlah keseluruhan DAU ditetapkan sekurang-kurangnya $26 \%$ (dua puluh enam persen) dari Pendapatan Dalam Negeri Neto.

(3) Proporsi DAU antara provinsi dan kabupaten/kota dihitung dari perbandingan antara bobot urusan pemerintahan yang menjadi kewenangan provinsi dan kabupaten/kota.

(4) Dalam hal penentuan proporsi sebagaimana dimaksud pada ayat (3) belum dapat dihitung secara kuantitatif, proporsi DAU antara provinsi dan kabupaten/kota ditetapkan dengan imbangan 10\% (sepuluh persen) dan $90 \%$ (sembilan puluh persen).

Dan PP No. 55 tahun 2005 Pasal 40 yaitu:

(1) DAU untuk suatu daerah dialokasikan berdasarkan formula yang terdiri atas celah fiskal dan alokasi dasar.

(2) Celah fiskal sebagaimana dimaksud pada ayat (1) merupakan selisih antara kebutuhan fiskal dan kapasitas fiskal.

(3) Kebutuhan fiskal sebagaimana dimaksud pada ayat (2) diukur dengan menggunakan variabel jumlah penduduk, luas wilayah, Indeks Kemahalan Konstruksi, Produk Domestik Regional Bruto per kapita, dan Indeks Pembangunan Manusia.

(4) Kapasitas fiskal sebagaimana dimaksud pada ayat (2) diukur berdasarkan Pendapatan Asli Daerah dan DBH. 
(5) Alokasi dasar sebagaimana dimaksud pada ayat (1) dihitung berdasarkan jumlah gaji Pegawai Negeri Sipil Daerah.

$$
\text { Bobot Daerah = Fiscal Needs-Fiscal Capmaxity }
$$

$$
\text { Fiscal Capacity = PAD - PSS- SPHTS - PPh - 750\%DA }
$$

Mardiasmo (160:2002)

Dimana bobot daerah ditentukan berdasarkan hasil pengurangan dari kebutuhan fiskal dengan kapasitas fiskal. Dan kapasitas fiskal merupakan penjumlahan dari PAD dan DBH. Sehingga dalam menentukan jumlah DAU yang diterima kabupaten dan kotamadya akan berhubungan dengan perolehan PAD dan $\mathrm{DBH}$ masing-masing pemda.

Dan secara konseptual terdapat hubungan antara pendapatan baik PAD maupun Dana Perimbangan (DBH dam DAU) dengan pembelanjaan secara keseluruhan. Hal ini dapat dibuktikan dengan hasil penelitian.

Berdasarkan penelitian empiris yang dilakukan oleh Holtz-Eakin et. al. (dalam Darwanto, 2007: 12) menyatakan bahwa "terdapat keterkaitan sangat erat antara transfer dari pemerintah pusat dengan belanja pemerintah daerah. Secara spesifik mereka menegaskan bahwa variabel-variabel kebijakan pemerintah daerah dalam jangka pendek disesuaikan (adjusted) dengan transfer yang diterima, sehingga memungkinkan terjadinya respon yang non-linier dan asymmetric".

Belanja Pemda menurut Halim (2002: 69) "belanja dapat dikategorikan menurut karakteristiknya menjadi dua yaitu belanja selain modal dan belanja modal". Berdasarkan Permendagri No. 59 tahun 2007 "belanja modal adalah pengeluaran yang dilakukan dalam rangka menambah aset tetap berwujud yang mempunyai nilai manfaat lebih dari dua belas bulan untuk digunakan dalam kegiatan pemerintah". Adapun jenis belanja modal menurut SAP terbagi kedalam enam pos, yaitu:

a. Belanja tanah

b. Belanja mesin

c. Belanja gedung dan bangunan

d. Belanja jalan, irigasi; dan lainnya

e. Belanja aset tetap lainnya

f. Belanja aset lainnya

Sedangkan menurut Abdullah \& Halim (2004) menemukan bahwa "sumber pendapatan daerah berupa pendapatan asli daerah (PAD) dan dana perimbangan berpengaruh terhadap belanja daerah secara keseluruhan". Sehingga dari dua bukti empiris tersebut dapat diketahui bahwa terdapat hubungan antara sumber pendapatan baik dari dalam daerah itu sendiri berupa PAD, maupun pendapatan dari transfer berupa dana perimbangan yang terdiri dari DAU dan DBH dengan belanja daerah secara keseluruhan, termasuk didalammnya belanja modal dan belanja selain modal.

Namun tidak selalu seluruh tambahan pendapatan akan dialokasikan dalam belanja untuk operasional, pemda akan melakukan alokasi pada belanja modal dan investasi yang benar-benar dapat dirasakan publik secara langsung. Menurut Moisio (dalam Halim, 2008: 14) menyatakan bahwa "orang akan lebih hemat dalam membelanjakan pendapatan yang merupakan hasil dari effort-nya sendiri dibanding pendapatan yang diberikan pihak lain (seperti grants atau transfer)". Ini berarti ada kemungkinan yang lebih besar untuk Pemda dalam melakukan alokasi yang lebih besar terhadap belanja modal setelah belanja operasional terpenuhi.

Dari hasil penelitian Darwanto dkk (2007) dengan menggunakan variabel DAU, PAD, dan pertumbuhan ekonomi, terhadap alokasi anggaran belanja modal menunjukkan bahwa DAU dan PAD berpengaruh positif terhadap alokasi anggaran belanja modal. Penelitian Darwanto tersebut dilakukan pada kabupaten dan kotamdaya se Jawa Bali dari tahun anggaran 2004-2005. Selain itu juga, Harianto dan Adi (2007) dengan mengunakan 
variabel DAU, PAD, Belanja Modal, dan Pendapatan per Kapita, menunjukkan bahwa DAU berpengaruh positif dan signifikan terhadap perubahan belanja modal dan begitu pula dengan PAD. Penelitian Harianto dan Adi tersebut dilakukan pada kabupaten dan kotamadya se Jawa Bali untuk tahun 2001-2004. Bukti empiris tersebut diperkuat dengan hasil penelitian Halim dan Abullah (2008) dengan menggunakan variabel belanja modal, belanja pemeliharaan, dan sumber pendapatan, menunjukkan bahwa sumber pendapatan daerah berupa dana perimbangan berhubungan positif terhadap belanja modal. Penelitian Halim dan Abdullah tersebut dilakukan pada sampel 20 kabupaten dan 12 kotamadya di Pulau Sumatra.

Dengan demikian, dari beberapa hasil penelitian yang telah dilakukan dan teori yang mendukung maka dapat disimpulkan bahwa alokasi anggaran belanja modal yang dilakukan oleh Pemda (eksekutif) bersama-sama dengan DPRD (legislatiif) pada APBD memiliki hubungan dengan sumber pendapatan baik dari dalam maupun dari luar yaitu berupa PAD, DAU, dan DBH.

$\mathrm{H}_{1} \quad$ Terdapat hubungan antara Pendapatan Asli Daerah, Dana Alokasi Umum, dan Dana Bagi Hasil secara parsial, dengan Anggaran Belanja Modal pada kabupaten dan kotamadya di Jawa Barat.

H2 Terdapat hubungan antara Pendapatan Asli Daerah, Dana Alokasi Umum, dan Dana Bagi Hasil secara simultan, dengan Anggaran Belanja Modal pada kabupaten dan kotamadya di Jawa Barat.

\section{Metode Penelitian}

Penelitian ini menggunakan metode korelasional, maka analisis yang dipakai adalah analisis korelasi. Analisis korelasi merupakan analisis untuk mengetahui ada atau tidaknya hubungan antara dua variabel atau lebih. Adapun populasi dan sampel yang digunakan dalam penelitian ini adaalah Laporan Realisasi Anggaran (LRA) APBD tahun anggaran 2007 pada kabupaten dan kotamadya di Jawa Barat yang berjumlah 25 pemda, kecuali Kabupaten Bandung Barat, dengan sumber data berasal dari Badan Pemeriksa Keuangan (BPK RI).

Pengujian hipotesis menggunakan analisis koefisien korelasi parsial dan simultan, dengan terlebih dahulu melakukan uji asumsi klaisk. Uji asumsi klasik merupakan syarat pengujian data sebelum dilakukan analisis dengan menggunakan analisis korelasi. Uji asumsi klasik diperlukan untuk memaksimalkan keakuratan pada hasil pengolahan data dan pengujian hipotesis yang dilakukan.

\section{Hasil Penelitian dan Pembahasan}

Hasil pengujian koefisien korelasi antara Pendapatan Asli Daerah dengan Anggaran Belanja Modal setelah dikontrol oleh variabel Dana Alokasi Umum dan Dana Bagi Hasil seperti terlihat paa tabel 1 adalah sebesar 0,191. Berdasarkan hasil pengujian tersebut dapat diketahui bahwa Pendapatan Asli Daerah memiliki hubungan dengan Anggaran Belanja Modal. Ini berarti menunjukkan bahwa hipotesis yang menyatakan terdapat hubungan antara Pendapatan Asli Daerah dengan Anggaran Belanja Modal diterima. Dan hubungan antara kedua variabel tersebut bersifat linier positif, dengan tingkat hubungan diantara kedua variabel sangat rendah. Walaupun hubungan diantara kedua variabel sangat rendah, tetapi pertumbuhan yang terjadi pada Pendapatan Asli Daerah menjadi perhatian tim anggaran pemda dalam pengambilan keputusan untuk melakukan alokasi Anggaran Belanja Modal pada tahun yang diteliti. Karena penetapan dan penggunaan Pendapatan Asli Daerah bisa dilakukan oleh pemda bersama DPRD tanpa adanya interpensi yang lebih dalam dari pusat, seperti yang diungkapkan oleh Mardiasmo (2002) dalam bukunya bahwa "Penggunaan PAD lebih leluasa dialokasikan 
oleh setiap pemda dibandingkan dana perimbangan yang ketentuannya telah ditetapkan melalui peraturan".

Tabel 1

Koefisien Korelasi Parsial Antara Pendapatan Asli Daerah dengan Anggaran Belanja Modal

\begin{tabular}{|c|c|c|c|c|}
\hline Control Variables & & & $\begin{array}{c}\text { Pendapatan Asli } \\
\text { Daerah }\end{array}$ & $\begin{array}{c}\text { Anggaran } \\
\text { Belanja Modal }\end{array}$ \\
\hline \multirow[t]{2}{*}{$\begin{array}{l}\text { Dana Alokasi } \\
\text { Umum \& Dana } \\
\text { Bagi Hasil }\end{array}$} & $\begin{array}{l}\text { Pendapatan Asli } \\
\text { Daerah }\end{array}$ & $\begin{array}{l}\text { Correlation } \\
\text { Significance (2-tailed) } \\
\text { df }\end{array}$ & $\begin{array}{r}1.000 \\
\cdot \\
0\end{array}$ & $\begin{array}{r}.191 \\
.382 \\
21\end{array}$ \\
\hline & $\begin{array}{l}\text { Anggaran Belanja } \\
\text { Modal }\end{array}$ & $\begin{array}{l}\text { Correlation } \\
\text { Significance (2-tailed) } \\
\text { df }\end{array}$ & $\begin{array}{r}.191 \\
.382 \\
21\end{array}$ & 1.000 \\
\hline
\end{tabular}

Tabel 2

Koefisien Korelasi Parsial Antara Dana Alokasi Umum dengan Anggaran Belanja Modal

\begin{tabular}{|c|c|c|c|c|}
\hline \multicolumn{3}{|l|}{ Control Variables } & $\begin{array}{c}\text { Anggaran } \\
\text { Belanja Modal }\end{array}$ & $\begin{array}{l}\text { Dana } \\
\text { Alokasi } \\
\text { Umum }\end{array}$ \\
\hline \multirow[t]{2}{*}{$\begin{array}{l}\text { Dana Bagi Hasil } \\
\text { \& Pendapatan } \\
\text { Asli Daerah }\end{array}$} & $\begin{array}{l}\text { Anggaran } \\
\text { Belanja Modal }\end{array}$ & $\begin{array}{l}\text { Correlation } \\
\text { Significance (2-tailed) } \\
\text { df }\end{array}$ & 1.000 & $\begin{array}{r}.312 \\
.147 \\
21 \\
\end{array}$ \\
\hline & $\begin{array}{l}\text { Dana Alokasi } \\
\text { Umum }\end{array}$ & $\begin{array}{l}\text { Correlation } \\
\text { Significance (2-tailed) } \\
\text { df }\end{array}$ & $\begin{array}{r}.312 \\
.147 \\
21\end{array}$ & 1.000 \\
\hline
\end{tabular}

Hasil pengujian koefisien korelasi antara Dana Alokasi Umum dengan Anggaran Belanja Modal setelah dikontrol oleh variabel Pendapatan Asli Darah dan Dana Bagi Hasil seperti terlihat pada tabel 2 adalah sebesar 0,312. Berdasarkan hasil pengujian tersebut dapat diketahui bahwa Dana Alokasi Umum memiliki hubungan dengan Anggaran Belanja Modal. Ini berarti menunjukkan bahwa hipotesis yang menyatakan terdapat hubungan antara Dana Alokasi Umum dengan Anggaran Belanja Modal diterima. Dan hubungan antara kedua variabel tersebut bersifat linier positif, dengan tingkat hubungan diantara kedua variabel adalah sedang. 
Tabel 3

Koefisien Korelasi Parsial Antara Dana Bagi Hasil dengan Anggaran Belanja Modal

\begin{tabular}{|c|c|c|c|c|}
\hline Control Variables & & & $\begin{array}{c}\text { Anggaran } \\
\text { Belanja Modal }\end{array}$ & $\begin{array}{c}\text { Dana Bagi } \\
\text { Hasil }\end{array}$ \\
\hline \multirow[t]{5}{*}{$\begin{array}{l}\text { Pendapatan Asli Daerah } \\
\text { \& Dana Alokasi Umum }\end{array}$} & \multirow[t]{2}{*}{$\begin{array}{l}\text { Anggaran } \\
\text { Belanja Modal }\end{array}$} & $\begin{array}{l}\text { Correlation } \\
\text { Significance (2- } \\
\text { tailed) }\end{array}$ & 1.000 & $\begin{array}{l}.648 \\
.001\end{array}$ \\
\hline & & df & 0 & 21 \\
\hline & \multirow{3}{*}{$\begin{array}{l}\text { Dana Bagi } \\
\text { Hasil }\end{array}$} & Correlation & .648 & 1.000 \\
\hline & & $\begin{array}{l}\text { Significance ( } 2- \\
\text { tailed) }\end{array}$ & .001 & \\
\hline & & df & 21 & 0 \\
\hline
\end{tabular}

Hasil pengujian koefisien korelasi antara Dana Bagi Hasil dengan Anggaran Belanja Modal setelah dikontrol oleh variabel Pendapatan Aslli Daerah dan Dana Alokasi Umum seperti terlihat pada tabel 3 adalah sebesar 0,648. Berdasarkan hasil pengujian tersebut dapat diketahui bahwa Dana Bagi Hasil memiliki hubungan dengan Anggaran Belanja Modal. Ini berarti menunjukkan bahwa hipotesis yang menyatakan terdapat hubungan antara Dana Bagi Hasil dengan Anggaran Belanja Modal diterima. Dan hubungan antara kedua variabel tersebut bersifat linier negatif, dengan tingkat hubungan yang terjadi diantara kedua variabel tersebut adalah kuat. Hasil koefisien yang kuat terjadi karena komponen Dana Bagi Hasil yang terdiri dari sumber daya mengalami kenaikan hasil pengolahan. Kenaikan hasil sumber daya alam terjadi bisa isebabkan oleh jenis dari sumber daya itu sendiri yang terdesia di suatu wilayah dan memiliki nilai ekonomi tinggi. Sehingga hasil yang diperoleh dari tahun ketahun mengalami kenaikan. Walaupun demikian, pertumbuhan yang terjadi pada Dana Bagi Hasil menjadi perhatian pemda dalam melakukan pengambilan keputusan untuk alokasi Anggaran Belanja Modal pada tahun yang diteliti. Dan menurut Halim dan Abdullah (2008: 3) menyatakan bahwa "Di sisi lain

Tabel 4

Hasil Koefisien Korelasi Simultan

\begin{tabular}{|c|c|c|c|c|}
\hline $\begin{array}{l}\text { Mod } \\
\text { el }\end{array}$ & $\mathrm{R}$ & R Square & $\begin{array}{l}\text { Adjusted R } \\
\text { Square }\end{array}$ & Std. Error of the Estimate \\
\hline 1 & $.684^{\mathrm{a}}$ & .467 & .391 & 43.67613 \\
\hline
\end{tabular}

Hasil pengujian koefisien korelasi antara Pendapatan Asli Daerah, Dana Alokasi Umum, dan Dana Bagi Hasil, secara simultan dengan Anggaran Belanja Modal seperti terlihat pada tabel 4 adalah sebesar 0,467. Berdasarkan hasil pengujian tersebut didapatkan bahwa semua variabel independen dalam penelitian ini secara simultan memiliki hubungan dengan variabel dependen. Ini berarti menunjukkan bahwa hipotesis yang menyatakan terdapat hubungan antara Pendapatan Asli Daerah, Dana Alokasi Umum, dan Dana Bagi Hasi secara simultan dengan Anggaran Belanja Modal diterima. Dan hubungan antara variabel dependen dan independen tersebut bersifat linier positif, dengan tingkat hubungan yang sedang diantara kedua variabel tersebut. Sehingga pertumbuhan yang terjadi pada pendapatan-pendapatan yang secara real diiterima menjadi perhatian pemda dalam melakukan pengambilan kebijakan untuk alokasi Anggran Belanja Modal pada tahun yang diteliti. 
Apalagi alokasi Anggaran Belanja Modal dikaitkan dengan komitmen pemda dalam memberikan pelayanan yang lebih baik kepada publik yang sudah menjadi sebuah kewajiban. Dan menurut halim dan Abdullah (2008:4) menyatakan bahwa:

Keputusan untuk meningkatkan belanja modal merupakan bagian dari keinginan untuk meningkatkan kualitas dan kuantitas pelayanan publik, yang diikuti dengan peningkatan belanja-belanja lain, yakni operasional dan belanja modal

Dengan demikian, setiap pertumbuhan yang terjadi pada sumber-sumber pendapatan daerah terutama Pendapatan Asli Daerah dan Dana Bagi Hasil memiliki hubungan dengan alokasi Anggaran Belanja Modal pada setiap pemda di Jawa Barta untuk tahun yang diteliti. Sedangkan setiap pertumbuhan yang terjadi pada Dana Alokasi Umum hampir tidak memiliki hubungan dengan alokasi Anggaran Belanja Modal.

\section{Simpulan}

Hasil pengujian secara parsial menunjukan bahwa Pendapatan Asli Daerah, Dana Alokasi Umum dan Dana Bagi Hasil memiliki hubungan dengan Anggaran Belanja Modal. Dan Pengujian secara simultan menunjukkan bahwa Pendapatan Asli Daerah, Dana Alokasi Umum, dan Dana Bagi Hasil memiliki hubungan dengan Anggaran Belanja Modal.

\section{Saran}

Hasil penelitian ini hendaknya dapat dijadikan acuan untuk melakukan penelitian lanjutan dengan memperluas wilayah penelitian dan memperpanjang periode waktu pangamatan serta dapat menambahkan faktor non keuangan yang akan diteliti seperti kepemimpinan kepala daerah, perilaku tim anggaran daerah, partisipasi DPRD, dan variabel bersifat eksternal seperti kelayakan belanja dan output serta outcome program bagi publik.

\section{Daftar Pustaka}

Abdul, Halim. 2002. Akuntansi Sektor Publik Akuntansi Keuangan Daerah. Jakarta: Salemba Empat.

Abdul, Halim. 2007. Seri Bunga Rampai Manajemen Keuangan daerah Pengelolaan Keuangan daerah. Yogyakarta: UPP STIM YKPN.

Abdul, Halim. 2008. Analisis Kinerja Keuangan terhadap Pertumbuhan Ekonomi, Pengangguran dan Kemiskinan dengan Menggunakan Analisi Jalur. Pontianak. Makasar: Simposium Nasional Akuntansi XI.

Abdyllah dan Halim. 2008. Studi atas Belanja Modal pada Anggaran Pemerintah Daerah Kaitannya dengan Belanja Pemeliharaan dan Sumber Pendapatan (Jurnal Akuntansi Pemerintahan). Jakarta:Departemen Keuangan RI.

Cornelius, Trihendradi. 2004. Memecahkan Kasus Statistik: Deskriftif, Parametrik Dan Non-Parametrik Dengan SPSS 12. Jogjakarta: ANDI.

Darwanto, dan Yustika yuliasari. 2007. Pengaruh PertumBUhan Ekonomi, Pendapatan Asli daerah, dan Dana Alokasi Umum terhadap Alokasi Anngaran Belanja Modal. Makasar: Simposium Nasional Akuntansi X.

David, Harianto. 2007. Hubungan antara Dana Alokasi Umum, Belannja Modal, Pendapatan Asli Daerah, dan Pendapatan Per Kapita. Makasar: Simposium Nasional Akuntansi X.

Dedi, Noerdiawan dkk. 2007. Akuntansi Pemerintahan. Jakarta: Salemba Empat.

Haryo, Kuncoro. 2007. Fenomena Flaypaper Effect Pada Kinerja Keuangan Pemerintah Daerah Kota dan Kabupaten di Indonesia. Makasar: Simposium Nasional Akuntansi X.

Imam, Ghozali. 2001. Aplikasi Analisis Multivariate dengan Program SPSS. Semarang: Badan penerbit UNDIP 
Mahmudi. 2006. Analisis Laporan Keuangan Pemerintah Daerah. Yogyakarta: ANDI. Mardiasmo. 2002. Otonomi dan Manajemen Keuangan Daerah. Yogyakarta: UPP STIM YKPN.

Mudrajat, Kuncoro. 2001. Metode Kuantitatif Teori dan Aplikas Untuk Bisnis dan Ekonomi. Jogjakarta: UPP STIM YKPN.

Murgiyantoro, dkk. 2004. Statistik Terapan. Jogjakarta: Gajah Madha University Press.

Mutiara, Maimunah. 2006. Flypaper Effect pada Dana Alokasi Umum (DAU) dan Pendapatan Asli Daerah (PAD) terhadap Belanja Daerah pada Kabupaten/Kota I Pulau Sumatra. Padang: Simposium Nasional Akuntansi IX.

Priyo, Hari Adi. 2006. Hubungan antara Pertumbuhan Ekonomi Daerah, Belanja Pembangunan, dan Pendapatan Asli Daerah. Padang: Simposium Nasional Akuntansi IX.

Priyo, Hari Adi. 2008. Relevansi Transfer Pemerintah Pusat terhadap Upaya Pajak Daerah. FE Universitas Katholik Widya Mandala.

Sugiyono. 2007. Metode Penelitian Bisnis (Pendekatan Kuantitatif, Kualitatif, dan R\&D). Bandung: Alfabeta.

Priyo, Hari Adi dan Wirawan Setiaji. 2007. Peta Kemampuan Keuangan daerah Sesudah otonomi daerah: Apakah Mengalami Pergeseran?. Makasar: Simposium Nasional Akuntansi X.

Santosa, Purbaya Budi dan Ashari. 2005. Analisis Statistik dengan Microsoft Excel dan SPSS. Jogjakarta:ANDI

Siddiq, Machfud. 2002. Perimbangan Pusat dan Daerah sebagai Pelaksanaan Desentralisasi Fiskal. Jogjakarta: Seminar Setahun Implementasi Otonomi Daerah di Indonesia.

Sugiono. 2007. Metode Penelitian Bisnis. Bandung: Alfabeta.

Suharsini, Arikunto. 1997. Prosedur Penelitian Suatu Pendekatan Praktek. Jakarta: Rineka Cipta. 2007. BAB 7 Desentralisasi Fiskal dan Kesenjangan Daerah (Kajian Pengeluaran Publik Inonesia 2007). Bank Dunia Perwakilan Di Jakarta.

UU No. 32 tahun 2004 tentang Pemerintah Daerah

UU No. 33 tahun 2004 tentang Perimbangan Keuangan Pusat dan daerah

PP No. 5 tahun 2005 tentang Dana Perimbangan

Peraturan Pemerintah Republik Indonesia Nomor 74 Tahun 2005 Tentang Dana Alokasi Umum Daerah Provinsi/Kabupaten/Kota Tahun Anggaran 2006.

Peraturan Pemerintah Republik Indonesia Nomor 104 Tahun 2006 Tentang Dana Alokasi Umum Daerah Provinsi/Kabupaten/Kota Tahun Anggaran 2007.

Peraturan Pemerintah Republik Indonesia Nomor 110 Tahun 2007 Tentang Dana Alokasi Umum Daerah Provinsi/Kabupaten/Kota Tahun Anggaran 2008. 